\title{
О нестручном напредовању и стручном назадовању
}

\author{
Жарко Војновић \\ Народна библиотека Србије, Београд \\ stevlovi@gmail.com
}

\begin{abstract}
Сажетак
Рад се бави анализом неколико начелних питања у вези са стицањем стручних звања у библиотечко-информационој делатности, кључних за схватање смисла стручног напредовања. Правилник о ближим условима за стицање виших стручних звања у библиотечко-информационој делатности и бодовна листа који регулишу стицање стручних звања извор су многих неспоразума и отворених злоупотреба. Њихова примена у пракси показала је да се углавном настоји на испуњавању формалних услова код кандидата. Принципијелна питања, попут тачнијег одређивања опсега библиотечкоинформационе делатности, процене квалитета, (не)оправданости начина вредновања редовних послова, као и праведности валоризације, доследно се избегавају. Све је то довело до хиперпродукције кандидатура, снижавања нивоа струке, због чега је замагљен и сам смисао стручног напредовања.
\end{abstract}

Кључне речи: стручна звања, библиотечко-информациона делатност, Правилник о ближим условима за стицање виших стручних звања у библиотечко-информационој делатности, бодовна листа, комисије, квалитет, вредновање

\section{Чему све то уопште служи?}

Како год да сам започињао писати за овај темат о стручним звањима, већ на првој реченици сам упадао у сатиру. Ето, укратко, какав је мој доживљај система који примењујемо последњих година - о њему ми је тешко говорити озбиљно, јер кад је озбиљно, може бити болно, а болних ствари је толико да су нам свима већ досадиле, нарочито зато што постаје све јасније да лека можда и нема. Или га има, али га нема у апотекама; или га тамо и има, али се даје само на рецепт, а лекар отишао у Немачку, па нема ко да га препише... Гле, сатира се опет сама гура у причу, хтео-не хтео... Него, да не бих узалуд развесељавао читаоце на погрешном месту, морам од ње на силу одустати, а друго - то ми овде ионако не би објавили. Ми библиотекари смо били смртно озбиљни, па смо изгледали и мртви... То нам беше досадило, па се сада трудимо да будемо занимљиви, да би некако били прихваћени, цењени и поштовани у време кад треба пре свега да се допаднеш. Како год било, ено моје сатире, која се зове „Како упропастисмо струку или жалосна исповест једног члана РКДВСЗБИД“,' сакрио сам је сам од себе у неку забачену фиоку нек чека своју судбину, можда се и нађе неко ко би то смео објавити. Јер се не може на бољи начин описати гротескна ситуација у коју смо сами себе довели, тобоже чувајући и унапређујући струку, која се зове библиотечко-информациона делатност (б\&д). Ово што следи биће стога прости и местимично жалосни опис тог лутања, без претензија на научну анализу.

Сетимо се најпре како је све то било лепо замишљено... Ранији правилник ${ }^{2}$ о звањима није имао скоро никакве критеријуме, па су се и звања додељивала по заслугама које се нису

\footnotetext{
1 Републичка комисија за доделу виших стручних звања у библиотечко-информационојделатности

2 „Правилник о ближим условима за стицање звања лица која обављају стручне послове у библиотеци“, Службени іласник РС бр. 63 (1994) и 18 (1997)
} 
прецизно мериле; неки су чак и успели да прескоче ниже, па дохватили одмах више звање. Пошто ипак није тако ваљало, размислило се, па се променио правилник, а епохална новост била је бодовна листа, у којој су поменуте заслуге разврстане поименично, по категоријама и врстама, и свакој је додељена одређена бројчана вредност. ${ }^{3}$ Рекло би се: то је прави пут да се осигурају једнака права и правила за све и да се на тај начин одмерава ни по бабу ни по стричевима. Нажалост, исправна логика и добре намере довеле су до праве збрке. Једна ствар је одмах у почетку постала сумњива. Наиме, док је за доделу звања важио стари, неексплицитни систем, пријава за стицање звања било је много мање; са применом новог система, чија је карактеристика бодовање, па је самим тим и строжији, долази до праве поплаве кандидација. Откуд то?

У сиромашном друштву као што је наше, новац је питање свих питања. По правилу, које не важи свуда, па зато и није правило, више звање подразумева вишу плату, а још више звање још вишу плату. Неколико хиљада динара неће у суштини човеку изменити живот, али их је дивно имати сваког месеца на рачуну, јер је то десет килограма меса више, што је врло опипљива егзистенцијална категорија. Разуме се да ће мало ко признати да је ово главни мотив, али требало би отворено рећи да се он у разговорима врло често чује. Што би рекла једна искрена колегиница: „Треба и моје дете 'леба да једе“. Све ми се чини, кад би ово економско начело постало неважеће, барем као нада, да би се број кандидатура прилично смањио. Осим тога, да се не љуте они којима паре можда и не требају, а требају им почасти и кићења, да поменемо и њих: звања су начин на који се ми, који за себе сматрамо да смо врх и ниво, разликујемо од оних који су дно и нису никакав ниво. Са становишта просечног библиотекара који би хтео да за живота ужива у сопственој слави, макар и најнижег интензитета, на том дну, без икаквог нивоа, живи огромна већина библиотекарских сатрудника, тачније - скоро сви. Па ако већ заслужујемо све почасти и права која из њих могу проистећи, онда се може десити и да неко, кад се звања дочепа, коначно започне свој метеорски успон до места некаквог шефа. Уз то, ми библиотекари јако болујемо због чињенице да нас нико не цени нити примећује. Ствар ипак изгледа мало боље кад се дође до макар какве почасти, па и у виду стручног звања.

\section{Награђивање и нагрђивање}

А сад на ствар која се тиче саме струке, мимо психологије личности. Најпре, у новом Правилнику је промењена одредба о годинама стажа потребним за подношење кандидатуре. ${ }^{4} \mathrm{He}-$ кад је библиотекар на то морао чекати десет година, што је била неправда за оне који су заиста располагали капацитетом и способностима и који су за неколико година рада претекли и оне што цео живот седе у библиотеци. Међутим, с друге стране, омогућено је, спуштањем границе на пет година, да се кандидују и они који поседују искључиво и једино амбицију, а схватили су како на брзину формално доћи до бодова, без обзира на то што су у правом смислу аналфабете. Овде већ долазимо до питања професионалне етике, које ми се чини као главна ствар и које се упорно понавља у свим аспектима овог проблема, а још се више види на озбиљнијим нивоима, попут универзитетског, где су вештине сналажења у долажењу до бодова невероватно еволуирале. Парадоксално, бодовна листа, која је требало да послужи као вага за тачно мерење, постала је извор недоумица и отворених злоупотреба, за којима посежу, ако им је то због нечега важно, чак и они који су управо у улози проценитеља.

Требало би прво зато рећи нешто о улози комисија, које су и у новом систему двостепене - матична и републичка. Приметно је да један број матичних комисија (свакако са изузетком

\footnotetext{
3 „Бодовна листа“, у „Правилник о ближим условима за стицање виших стручних звања у библиотечко-информационој делатности“, Сл. іласник РС бр. 22 (2013): [6-9].

${ }^{4}$ „Правилник о ближим условима за стицање виших стручних звања у библиотечко-информационој делатности“: [4].
} 
оних у националним библиотекама) делује искључиво као административно тело које оверава, али не проверава. Углавном, у својим извештајима о кандидатима не доводе у питање квалитет саме кандидатуре, па колико бодова ко пријави, оне толико и верификују као коначан резултат, без икаквог критичког осврта на достављени материјал. Зато веома узбудљиво може изгледати даљи ток догађаја, кад неки кандидати, којима је матична комисија приписала, по њиховој жељи, рецимо 63 бода, на Републичкој комисији остану само на три, што изазива прави шок кандидата кад такав поразан резултат дође до њега. Из тога би неко лако могао извући злобан закључак да су чланови матичних комисија у том случају очигледно мање стручни од кандидата чијим би радом требало да се позабаве, јер да је другачије, обавили би свој посао барем у некој мери. Републичка комисија стога стварно мора неупућеном кандидату и његовој локалној комисији изгледати као инквизиција. Ипак, не бих превише кривице сваљивао на сироте матичне комисије, које су се, с једне стране, нашле у незахвалној позицији да тумаче бодовну листу без чврстих упутстава, ${ }^{5}$ а с друге стране, пошто изузетно ретко заседају, немају прилике да стекну потребно искуство и праксу, нити су имале одакле да се науче у ситуацији кад и у Републичкој комисији постоје оштро супротстављени ставови скоро око свега што стоји у бодовној листи.

Један од основних проблема у њеном тумачењу јесте питање шта се све од онога што библиотекари раде може бодовати. Тачније: 1. шта спада у б\&д, а шта не и 2. да ли се бодује оно што спада у тзв. редован посао.

Око овога, мишљења су апсолутно опречна. Чини се да је последњих година, кад традиционална улога библиотека због промена у друштву нестаје, због чега оне покушавају да се баве и оним што не спада у њихову традиционалну делатност, критеријум за одређивање опсега библиотекарске и библиотекарских делатности постао врло нејасан. Библиотекари, у недостатку класичних корисника, који су се врло проредили, у библиотекама одржавају свакојаке "програме", „креативне радионице“ итд., за које никад није сигурно да ли и по чему одговарају захтевима бодовне листе. Није јасно, наиме, да ли баш свака таква ствар - нпр. обука за пензионере у кориштењу рачунара - спада у библиотечку делатност само зато што се одвија унутар библиотеке (а може да се одвија и на било ком другом месту). У оваквим ситуацијама потеже се аргумент корисности, чији заступници на евентуално противљење одговарају: „Да, али то је за њих тамо корисно“, иако се на тај начин неминовно уноси елемент произвољности, јер не постоји никакав критеријум којим би се то дало доказати. Овако долазимо до неугодне ситуације да се делатности које су библиотекама законски поверене и за које је потребно не само познавање струке, него и стваралачки однос према њој, изједначавају са онима које су факултативног карактера - тј. може да их буде, али уопште не мора - и немају суштинске везе са самом струком. То изазива не само недоумице у њиховој комисијској процени, него и сукобе између оних који обављају оно без чега библиотека не може и оних који раде оно без чега она може. Са друге стране, постоје одлични примери уношења нових пракси које нису блиске класичном библиотекарству и које управо показују сву јаловост библиотекарства схваћеног само као уска струка и некаква још од леденог доба аутоматизована, нестваралачка делатност.

Ово питање се нарочито добро да илустровати на примеру прве групе бодовне листе, која вреднује текстове. ${ }^{6}$ Оно се увек првенствено јавља у истом облику: шта је библиотекарска тема, а шта није. Рекло би се да је за већину текстова то само по себи јасно, али постоји велика сива зона као резултат већ описаног недостатка јасног критеријума. И овде су мишљења супротна, од оних који мисле да све што је неки библиотекар написао самим тим спада у струку,

\footnotetext{
5 Постоји једно интерно и крајње недовољно тумачење: „Закључци са заједничког састанка Републичке комисије за доделу виших стручних звања у библиотечко-информационој делатности са председницима матичних комисија“, Народна библиотека Србиje, 13. септембар 2013. године, преузето 1. 3. 2019, https://www.nb.rs/view_file.php?file_id=3939.

6 "Бодовна листа“, у „Правилник о ближим условима за стицање виших стручних звања у библиотечко-информационој делатности": [6-7]
} 
до оних који тврде да је струка омеђена у свим случајевима једноставним критеријумом који каже: еминентно библиотекарско је само оно што може обавити једино библиотекар, и нико други. Ако примењујемо прво схватање, може се бодовати апсолутно све, без обзира на садржај, при чему сама струка губи обрисе; друго схватање нас ипак тера да о томе макар размишљамо и да тражимо компромисе тамо где их може бити. Чињеница је да у библиотекама има оних који се много квалитетније баве оним што је предмет њиховог образовања, нпр. биологијом, док се за библиотекарство слабо интересују. Ипак, покушамо ли уопште утврдити било какав критеријум, неће бити тешко да појмимо како текст о врстама цвећа на планини Јелици неће моћи да се бодује у оквиру библиотечко-информационе делатности, док би, рецимо, библиографија текстова о планинском цвећу била свакако прихваћена, а то је ствар коју би сваки библиотекар морао бити кадар извести; нарочито би радо била дочекана студија о благотворном дејству шарене флоре на хроничну депресију од које пате библиотекарке. Тако исто и историографска студија о Нићифору Дучићу као управнику Народне библиотеке Србије, али тешко да би у обзир ушао и рад о њему као богослову. Нажалост, и у Републичкој комисији можемо врло често чути, од оних који пате од вишка разумевања за библиотекаре и љубави за човечанство, наопаку ствар да је све то свеједно, и да је рад о шумарству у неком крају исто што и рад о историји књиге тог краја. Аргументација је иста: „Али то је њима важно!" Јесте, али се може вредновати у оквиру неких других делатности, а ако је библиотекар имао воље, времена и слободног простора да се тиме бави, биће на понос својој средини. Или: има библиотекара, пишу поезију. Може се десити да је неко од њих као Бодлер: не разумемо га данас, али разумеће га они сутра. Ипак, још ниједна збирка поезије није оцењена као допринос б\&д. Ко зна, можда грешимо. Што су песници гори од шумара?

Посебна недоумица настала је око питања свакодневног, редовног рада, тј. има ли основе да се он бодује или не. И овде су, погађате, мишљења супротна. Поменути љубитељи човечанства и заклети пријатељи свих библиотекара на свету кажу ово: библиотекари не би требало ништа посебно и мимо тога да раде; ми смо толико важни да сама чињеница да је неко долазио на посао неколико година довољна да се истом додели звање без размишљања, само ако још покаже и жељу да то звање добије, и рецимо једном у животу напише како то њему изгледа кад он ради са корисницима. На тај начин ми, наводно, своју струку вреднујемо како треба, јер јој дајемо на значају колико треба. Све би то била само једна бурлескна сцена, да то стварно и не функционише тако, и то као неправда. Заиста, у нашој бодовној листи, у осмој групи, ${ }^{7}$ свако може себи уписати колико је „записа“ сам саставио, а колико преузео. Такав је посао нас библиотекара: ми, иначе, каталогизирамо. То је највидљивији знак библиотекарства. У старо време се говорило да је то његова основа, а и данас су неки склони таквим редукционистичким идејама, иако је година 2019. Па ако довољан број година каталогизираш, а пет је свакако довољно, ти ћеш на тај начин стећи 45\% бодова за прво више звање без по муке. Ако пак не каталогизираш, сам си крив. Мораћеш ипак да порадиш нешто више мимо свог основног посла, што ми каталогизатори не морамо. Ово је, наравно, сметало само онима који немају ту привилегију да са фамозном „књигом у руци“ безболно зараде скоро половину бодова, а чији се редовни посао не рачуна ни у шта са становишта бодовне листе, у чијем је састављању ваљда најгласнији био онај ко није схватао да у библиотекарству има и других послова поред оних у електронској бази; док се сви остали обилато користе том незаслуженом бенефицијом. На то је свакако утицао факт да се код нас уврежило схватање да нема библиотекарства ван фамозног Кобиса, и да је то најмудрија ствар која је икад постојала. Неко је, дакле, морао написати књигу у свом слободном времену, а неко седео и за плату обрађивао неколико књига дневно. И то је све, насилном нивелацијом, постало исто. 
Кључно питање овог проблема у ствари је ово: колико је оправдано уопште додатно вредновати рад који је већ вреднован платом коју је библиотекар примио? Питање је начелно, из њега апстрахујемо чињеницу да су плате никакве. Ако се од библиотекара не захтева додатан посебан напор, у чему је онда разлика између оних који примају плату, али унапређују рад, и оних који плату само примају, а посао обављају механички? Готово никаква. Ако се на силу изједначавају они који стварају и они који једва и без воље, уз то и неквалитетно, шалтерски репродукују - а немојмо се правити да то није основна разлика - цела идеја стручних звања постаје бесмислена, јер и сам рад, ако га не прати праведна сатисфакција, постаје обезвређен и обесмишљен. Савесно обављање посла требало би пре свега да се огледа у препоруци за звање коју ће кандидат добити; уз то, тешко да би препоруку требало да добије онај ко основно занимање не обавља како ваља, чиме наноси штету процесу рада, показујући самим тим свој однос према струци у оквиру које би хтео стручно звање. Наравно, у пракси бива и да се поједини кандидати чак и на Републичкој комисији насилно промовишу у звања и без икакве препоруке руководиоца, ако постоји интерес, без обзира да ли ишта вреде као радници. Притом, направимо битну разлику: увек има оних који струку гурају напред, оригиналним решењима и иновацијама, што је свакако, иако се одвија у оквиру редовних послова, посебна вредност. Ако такву врсту креативности оставимо само као питање нечије савести, онда смо упропастили још једног ентузијасту. Савест у човека је лако кварљива ствар, ако се повремено не подупре каквом било врстом сатисфакције, увенуће, а ентузијазам нестати кад се после дугог низа година рада по принципу „perpetuum mobile“, схвати оно што је по нашим библиотекама правило: општа уравниловка у условима функционисања друштвене имовине, која је ничија и за коју нико није одговоран. Садашњи резултати у оквиру система доделе стручног звања недвосмислено показују да се фаворизују они који су успели да пре свега испуне формалне услове, па на крају испадне свеједно да ли си архитекта или НКВ зидар.

Тако дођосмо и до питања квалитета. Како сада ствари стоје, чланови свих комисија сматрају да није њихов посао да разматрају квалитет материјала, него само да одлуче да ли је категорисан како треба, тј. да ли су испуњени формални услови, па ако јесу - ето и бодова. Ево како то изгледа. Да ли је ово „монографска публикација“ (ружно име за књигу)? Јесте. Да ли спада у б\&д? Сигурно спада, види се по наслову. А да ли оно што је у њој одговара стандардима струке, коју ми чувамо, унапређујемо, итд.? Е па то није важно; чим је објављено, значи да одговара. Има ли рецензената, то се ни не сме питати. И нема везе што несретни аутор нема основног појма о ономе о чему пише, што то не може да прође чак ни критеријуме постављене на стручном испиту, и што ни наслов не одговара садржају. Наслов, рецимо, каже да се публикација бави старом и ретком књигом, а у садржају тога има само у траговима, из чега би ваљало закључити не само да аутор остаје без бодова, него да би опет требало да иде на стручни испит, где се такве ствари уче. Наравно, ништа се од тога неће десити, јер нас, као што рекосмо, то и не занима. Или, на пример, на сто дође какав текстић од четири стране формата A5, објављен на неком тзв. стручном скупу, и то тобоже међународном, од чега је на три стране као некаква библиографија, а у остатку се као објашњавају све саме невиђене и премудре ствари: како је то библиографија, како је то рађено по стандарду, па чак и de visu, и наравно извучено из електронске базе аутоматским путем. Такав епохални урадак потписан је трима именима, јер је очигледно било изузетно напорно изборити се са таквим тешкоћама без удруженог рада. Па иако је сваком јасно да се ради о обичном отпатку, који апсолутно штети угледу струке, наше комисије се снебивају да то назову правим именом, руководећи се идејом: чим је то објављено, значи да ми ту немамо о чему да разговарамо. И тако наше славне ауторке добију без по муке три бода. Контрола квалитета је и иначе нешто што код нас углавном не постоји; важно је испуњавање форме. Уз то, већинско суперфилантропско расположење у Републичкој комисији је такво да се неким кандидатима, ако се оцени да су важни или за нешто (а можда и против неког) потребни, бодови и измишљају, као и да им се признаје оно што се никоме принципијелно раније није признавало, већ према потреби. 
Додајмо овде и нешто о ономе што се колоквијално зове „навлачење бодова“. Наиме, Републичка комисија функционише и као Прокрустова постеља. Утврди ли се да кандидату недостаје један или један и по бод, онда се са осећањем саучествовања приступа поновном разматрању његовог доприноса, јер је штета да остане без звања, кад је већ тако далеко догурао, тј. до неких 9 бодова за ко зна колико година вредног и преданог библиотекарског рада. Ту почиње право лицитирање: шта и како признати да се он на силу довуче до жељеног циља, где и како наћи оно што недостаје за срећу, да не бисмо били криви за евентуалну његову патњу. Овом добротворачком, старатељском принципу тешко се може супротставити, иначе се ризикује да се изађе на јако рђав глас, а слабо ко жели да страда од колегијалне омразе.

Овај је проблем у ствари уско скопчан са професионалним моралом. Питање је: без обзира на мотиве онога што зовемо „стручно напредовање“ (а код нас је стручно напредовање кад добијеш више звање, а не кад заиста постигнеш боље резултате у струци и дођеш до неких нових знања и добрих резултата), да ли је дозвољено користити средства која су са становишта етике сумњива? Ово се тиче не само кандидата, него и комисије, која би требало да филтрира, процењује и на крају оцењује. Претходно наведени пример троструког ауторства у случају безвредног и невеликог текста, чега код нас има много, пример је заобилажења професионалних етичких норми, које, наравно, нису нигде записане и канонизоване, али се међу пристојним људима подразумевају. Све је то довело до хиперпродукције бесмислених написа која тако обесмишљава и потребу не само за научном, него и пуком стручном делатношћу. Комисије у овоме учествују тако што се у свој посао не мешају, него углавном региструју формалну исправност. Оваквих злоупотреба највише је у случају библиографије, што је тема толико озбиљна да заслужује посебан текст. За ову прилику требало би рећи да је могућност добијања аутоматских исписа из поменутог Кобиса пружила могућност врло јефтиног долажења до библиографских производа, који се потом, не само без озбиљније библиографске анализе, него и без краћег стручног осврта, пуштају у јавност, заједно са свим грешкама које аутоматски испис собом носи, а третирају се као стручни радови. Ова наопака пракса толико је раширена да готово више и нико не схвата шта ту није у реду. Приметно је и још нешто: како неки стекну највише звање, тако им некако и опадне интересовање за даљим подвизима.

Ово нас директно доводи и до питања неравнотеже у бодовању. Ако је могуће за горепоменуту ствар инкасирати три бода, рекло би се да се за научни теоретски текст од педесет страна може добити барем тридесет. Нажалост, грдно смо се преварили: понекад није могуће добити више од једног и по бода. Због чега је то тако? Зато што творци бодовне листе нису схватили да није довољно само констатовати да је нешто објављено у категоризованом часопису. ${ }^{8}$ Наиме, разлика међу њима је огромна; она се у оквиру националних часописа креће од M24 до M53 (у оквиру чега постоји и категоризација самих текстова - од оригиналног научног рада до стручног рада), при чему се код првих углавном ради о врло старим и угледним публикацијама које одржавају ниво квалитета, док код последњих увек има оних који су на граници да остану без категоризације. Другим речима, није исто ако се објави обиман научни рад (има и таквих библиотекара) у, рецимо, тако старом и реномираном ча-

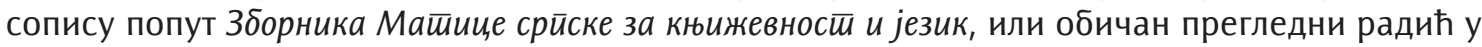
неком часопису који је тек доспео до групе M53, а ко зна да ли ће се у њој задржати. Дакле, не само да се ни теоретски не поставља питање квалитета и задовољавања стандарда, тј. да ли је баш све зрело за бодовање, него се и оно што представља врхунски домет механички спушта и изједначава с оним што ничему не вреди. Од свега овога је још гора чињеница да се текстови објављени у зборницима са стручних скупова аутоматски више вреднују (са два бода) од горепоменутих, иако и за њих вреди све што је раније речено, тим више што је

8 "Pravilnik o postupku, načinu vrednovanja i kvantitativnom iskazivanju naučnoistraživačkih rezultata istraživača”, Sl. glasnik RS br. 24 (2016) i 21 (2017), preuzeto 1. 3. 2019, http://www.mpn.gov.rs/wp-content/uploads/2017/03/Pravilnik-2017-preciscentekst.pdf. 
добро познато да је и општи квалитет самих ових зборника често на врло ниском нивоу. Није ни то све: у случају да је организатор свој скуп помпезно назвао међународним (а код нас се мисли да је скуп међународни ако на њему учествује, уз двадесет излагача из Србије, и један из БиХ или, рецимо, Бугарске), за такву ствар се добију и цела три бода. Ерго: требају ли ти бодови, напиши било како и било шта што знаш да ће ти бити објављено на неком од тих фамозних међународних скупова, па још један такав, плус „бодови из Кобиса“ и завршио си посао; свакако си испао мудрији и способнији од онога што је за научни рад, само зато што је објављен у тамо некој Књижевној исшиорији, стекао тек пола од тога, а сирома „нема ништа из Кобиса", па мора још да се труди.

Лутање у овим категоријама свакако је последица несналажења у свету науке, одакле су овакви системи и потекли и где имају природно оправдање. Библиотеке нису научне институције и неће никад бити, а у њима изгледа не раде научници; због тога је било потребно консултовати колеге са универзитета, како би се и нама неке ствари разјасниле. Међутим, тога није било, вероватно из медиокритетске суревњивости, а изгледа да неће ни бити, па смо очигледно осуђени на даља спотицања, пошто ове проблеме не можемо самостално савладати. То је свакако стога што је библиотекарство првенствено практична делатност, а библиотекари практичари, па нам је тешко да своје послове теоретски апстрахујемо. Зато су и теоретски доприноси б\&д толико ретки да се чини као да их нема, а ако се и појаве, нико их и не примећује, јер испадају из хоризонта уобичајених очекивања. Уместо тога, имамо бескрајна и досадна препричавања праксе.

\section{Куда пођосмо и где дођосмо}

Намера овог текста није била анализа бодовне листе и свих њених недостатака, нити поку-

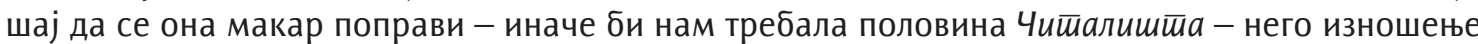
начелних примедаба на очигледно погрешна решења која су довела до наопаких резултата. Ефекат примене оваквог система доделе стручих звања аналоган је учинку Болоњског система на научни рад: све више стручних, стручнијих и најстручнијих кадрова, а све мање квалитета међу њима. Формално напредовање превише личи на назадовање. Како ствари стоје, ако до даљег на снази остане забрана запошљавања, а стручна звања и даље буду олако дељена на све стране, на крају у неким библиотекама више и неће бити нити једног старог, доброг, поштеног, обичног библиотекара. Не треба уопште сумњати у то да они који нас плаћају (иако плаћају као да себи од уста откидају) неће наше добре намере, нашу неутољиву жеђ за стручним напредовањем, схватити како би требало и да ће на нашу уравниловку одговорити својом, што би био сасвим логичан и очекиван одговор на изградњу овог вештачког пантеона стручњакиња и стручњака. Наша звања претворили смо у социјално-психолошку категорију, одвајајући их тако од струке, која зато трпи све већу медиокритетизацију. Тужна утеха је да смо по томе ипак у потпуном складу са тренутним друштвеним тенденцијама. ${ }^{9}$

\footnotetext{
${ }^{9}$ А онај доктор што је отишао у Немачку и безуспешно се трудио да упадне у ову причу, можда ће ипак једног дана успети да нађе лек и препише рецепт за наше хроничне болести, наравно, ако успе од силних синекурџија који су зајахали библиотеке, а библиотекаре презиру и омаловажавају. То је други пол историје распадања која се зове „Како упропастише струку“. Време је да се и та историја пресели из фусноте у главни део текста.
} 


\title{
Литература и извори:
}

1. "Pravilnik o bližim uslovima za sticanje viših stručnih zvanja u bibliotečko-informacionoj delatnosti". Službeni glasnik RS br. 22 (2013).

2. "Pravilnik o bližim uslovima za sticanje zvanja lica koja obavljaju stručne poslove u biblioteci“. Službeni glasnik RS br. 63 (1994) i 18 (1997).

3. „Pravilnik o postupku, načinu vrednovanja i kvantitativnom iskazivanju naučnoistraživačkih rezultata istraživača". Službeni glasnik RS br. 24 (2016) i 21 (2017). Preuzeto 1. 3. 2019. http://www.mpn.gov.rs/ wp-content/uploads/2017/03/Pravilnik-2017-preciscen-tekst.pdf.

4. „Zaključci sa zajedničkog sastanka Republičke komisije za dodelu viših stručnih zvanja u bibliotečkoinformacionoj delatnosti sa predsednicima matičnih komisija“. Narodna biblioteka Srbije, 13. septembar 2013. godine. Preuzeto 1. 3. 2019. https://www.nb.rs/view_file.php?file_id=3939.

\section{About Unprofessional Advancement and Professional Decline}

\begin{abstract}
Summary
It was considered that the adoption of the new rule book on professional titles and the score list as a measuring instrument established a correct and just system for determining the exact contribution to library and information activity. However, it turned out that unclear criteria and the lack of understanding of basic principle issues led to a counter-effect. The expectation of linking the acquisition of professional titles to the material reward has caused a real flood of candidacies, many of which are therefore questionable, because the set requirements are being met only formally. Commissions in libraries and the Republic Commission failed to respond to the challenge in a principled way, wherein there are too many diametrically opposed attitudes. Unresolved basic issues are the main problem. The possibility and the need to evaluate the quality of the reported elements within the score list of a candidate are rejected, under the pretext that it is not a matter for the commission. In addition, the criteria for determining the more accurate range of library and information activities are unclear, which leads to inevitable arbitrariness, and in the case of different candidates, the same thing is recognized or not recognized, as required. Another major issue is whether the regular work, done during working hours and for which the employee is paid, should be automatically accepted for evaluation within the score list, which has caused unjustness in assessment, favoring some and denying other candidates. This has led to lowering the level of the profession and the idea of professional advancement has lost sense.
\end{abstract}

Keywords: professional titles, library and information activity, Rule Book on Detailed Requirements for Obtaining Higher Professional Titles in Library and Information Activity, score list, commissions, quality, evaluation 


\section{(c) $(\mathcal{O} \Theta \Theta$}

О нестручном напредовању и стручном назадовању bу Жарко Војновић is licensed under a Creative Commons Attribution-NonCommercial-NoDerivatives 4.0 International License. 